\title{
WATER HYACINTH-BASED LIQUID ORGANIC FERTILIZER INCREASED GROWTH AND YIELDS OF ORGANICALLY GROWN CUCUMBER
}

\author{
${ }^{1}$ Dedi Rian Rohmawan, ${ }^{2}$ Zainal Muktamar, ${ }^{1 *}$ Fahrurrozi Fahrurrozi \\ ${ }^{1}$ Department of Crop Production, University of Bengkulu, Bengkulu, 38121, Indonesia \\ ${ }^{2}$ Department of Soil Science, University of Bengkulu, Bengkulu, 38121, Indonesia \\ ${ }^{*}$ Corresponding author
}

DOI: https://doi.org/10.51193/IJAER.2020.6608

\begin{abstract}
The use of liquid organic fertilizer (LOF) has been increasingly practice to improve the effectiveness of solid organic fertilizer application in the production of many vegetable crops. Proper selection of green biomass must be taken into account since type of green mass determines the nutrient contents in LOF. Water hyacinth is a green biomass that widely grows water ecosystem around the vegetable growing area and is considered as a promising source of biomass for LOF production. This experiment aimed to determine the optimum concentration of water hyacinth-based LOF for growth and yields of cucumber. A complete randomized design experiment was established with three replicates. Treatments consisted of $0 \%, 20 \%, 40 \%, 60$ $\%, 80 \%$ and $100 \%$ concentrations of water hyacinth-based-LOF. Results indicated that the use of water hyacinth LOF significantly increased leaf number, shoot fresh weight and shoot dry weight. In addition, the use of water hyacinth LOF also significantly increased fruit diameter, fruit length, fruit weight and fruit hardness of cucumbers. The application of $100 \%$ of water hyacinth LOF was the best concentration to increase cucumber growths and yields.
\end{abstract}

Keywords: Cucumber; Liquid Organic Fertilizer; Water Hyacinth.

\section{INTRODUCTION}

Cucumber (Cucumis sativus L.) belongs to family of Cucurbitaceae and is very popular vegetable crops which could be consumed as fresh vegetables for salad or as processed products. High nutrition contents and other medicinal purposes are among the reasons for the consumers to make use of this plant (SUMPENA, 2001). Consumer demands for organically grown 
International Journal of Agriculture and Environmental Research

ISSN: 2455-6939

Volume: 06, Issue: 06 "November-December 2020"

vegetables, including cucumber, have been notably increasing during the last two decades since many people are getting more educated and prosperous. Such phenomenon is also true for many Indonesian consumers (SUHARJO et al., 2016).

The use of solid organic fertilizer in organic vegetable productionhas been commonly practiced for nutrient supply to vegetable crops. However, the use of liquid organic fertilizer (LOF) increased the effectiveness of solid organic fertilizer for vegetable crops and was reported to increase yields of sweet corn (MUKTAMAR et al., 2016) and carrots (FAHRURROZI et al., 2015). The production of LOF was conducted by aerobically composting of various organic materials, including animal feces and urine, green biomasses, effective microorganisms, water and other locally available elements (FAHRURROZI et al., 2016). All those materials were further incubated for three to four weeks in closed container. Since green biomass is one of the main component to determine nutrient contents of LOF, proper selection of green biomasses must be taken into account. Water hyacinth (Eichhornia crassipes Mart.) is a green biomass that abundantly available in the surrounding areas of vegetable productions and is considered as weed in water ecosystems. According to HAJAMA (2014), this weed had $36.59 \%$ of organic matter, $21.23 \%$ of organic carbon, $0.28 \%$ of N-total, $0.001 \%$ of P, and $0.016 \%$ of K-total. Recently, FAHRURROZI et al. (2017) identified nutrient content of water hyacinth and concluded that in a dry weight basis, biomass of E. Crassipes contained $4.17 \% \mathrm{~N}, 0.32 \% \mathrm{P}, 4.07 \% \mathrm{~K}, 10.50 \mathrm{Me}$ $100 \mathrm{~g}^{-1}$ of Ca-ex. and $4.00 \mathrm{Me} 100 \mathrm{~g}^{-1}$ of $\mathrm{Mg}$. Since its high content on $\mathrm{N}$ and $\mathrm{K}$, this weed could serve as a source of biomass for LOF production.

Similar to application of other liquid fertilizer in vegetable production, LOF concentration is one of the determinant factors for the successfulness of LOF application. According to MOI et al. (2015), the use of water hyacinth-based LOF had been reported to increased yields of caisims (Brassica juncea L.). However, there has been limited information on how LOF using green biomass water hyacinth as the nutrient sources affect cucumber growth and yields. This experiment was designed to determine the optimum concentration of water hyacinth-based LOF for growth and yields of cucumber.

\section{MATERIALS AND METHOD}

An experiment was conducted at Faculty of Agriculture, University of Bengkulu at the elevation of 10 meter above sea level. A single factor experiment of complete randomized design was established with three replicates. Treatments consisted of six concentrations of water hyacinthbased-LOF; $0 \%, 20 \%, 40 \%, 60 \%, 80 \%$ and $100 \%$ LOF. Each treatment consisted of two plants grown in separated polybag. 
International Journal of Agriculture and Environmental Research

ISSN: 2455-6939

Volume: 06, Issue: 06 "November-December 2020"

Production of water hyacinth-based LOF was conducted by mixing $5 \mathrm{~kg}$ fresh cattle's feces, 10 cattle's urine, $2.5 \mathrm{~kg}$ of topsoil, $5 \mathrm{~kg}$ of E. Crassipes leaves, $10 \mathrm{~L}$ solution of 24-hour incubated $10 \mathrm{~mL}$ EM $4+0.125 \mathrm{~kg}$ white sugar in a blue plastic container to make incubated LOF mixture. These mixtures were added with water to reach a volume of $100 \mathrm{~L}$, securely covered and incubated for five weeks.

Growing media was arranged in black polyethylene polybags contained $10 \mathrm{~kg}$ (absolute weight) of top soil of ultisol and mixed with $50 \mathrm{~g}\left(10\right.$ ton $\left.\mathrm{ha}^{-1}\right)$ of cattle based organic fertilizer. This experiment used cultivated variety cucumber of Camri F1. Seeds were soaked with warm water for five hours and then placed in moisten tissue paper for 24 hours. Each polybag was originally planted with two moisten cucumber seeds in 3 to $5 \mathrm{~cm}$ depth and covered with top soil. After a week of planting, one of the worse seedlings was removed from the polybag to leave a single plant in each polybag. In each plant, a bamboo stakes of $1.6 \mathrm{~m}$ height was stood up next to the polybag.

Every single plant received a total of $950 \mathrm{~mL}$ LOF according to treatments and was sprayed uniformly to plants as much as 50,100,150,200, 250 and $200 \mathrm{~mL}$ at 7, 14,21,27, 35, and 42 days after planting. The applications of LOF were conducted at 07.00-09.00 a.m by uniformly spraying the fertilizer to cucumber plants.

Plants were manually irrigated, when there was no precipitation, until the growing medium reached field capacity, indicated by dripping water from the bottom of polybag. All weeds, pests and diseases were physically controlled by removing their presence in the polybags. Cucumbers were harvested at 7 weeks after planting. Due to water flooding, the experiment was ended up after the first harvest.

Treatments' effects on cucumbers were measured by in terms of leaf number, shoot fresh weight $(\mathrm{g})$, shoot dry weight $(\mathrm{g})$, fruit weight $(\mathrm{g})$, fruit diameter $(\mathrm{cm})$, fruit length $(\mathrm{cm})$, and fruit hardness $\left(\mathrm{kgf.cm}^{2}\right)$. Data was subjected to homogenous test before analysis of variance by using the Statistical Analysis System at $\mathrm{P}<0.05$. The relationship between each significant variable and concentrations of water hyacinth-based LOF was determined by using orthogonal polynomial at $\mathrm{P}<0.05$.

\section{RESULTS AND DISCUSSION}

Laboratory analysis indicated that nutrient contents of water hyacinth-based liquid organic fertilizer (LOF) were $3.08 \%$ of N-total, $1.06 \%$ of $\mathrm{P}$ and $0.33 \%$ of $\mathrm{K}$. These contents complied with standard of LOF issued by Ministry of Agriculture, Republic of Indonesia (MINISTRY OF AGRICULTURE, 2019). According to this standard, $\mathrm{N}, \mathrm{P}_{2} \mathrm{O}_{5}$ and $\mathrm{K}_{2} \mathrm{O}$ of liquid organic fertilizer must range from 2 to $6 \%$. 


\subsection{Cucumber growth}

Results indicated that the application of water hyacinth-based LOF significantly influenced leaf number, shoot fresh weight and shoot dry weight. Relationship between the application of water hyacinth-based LOF and leaf number of cucumber had a linear relationship $(y=13.16+0.095 x$, $\mathrm{R}^{2}=0.604$, Figure 1). This suggested that $60.4 \%$ of increased leaf number was resulted from LOF application. Cucumber grown without LOF application had 13.83 leaves, and those applied with $100 \%$ LOF produced 24.33 leaves.

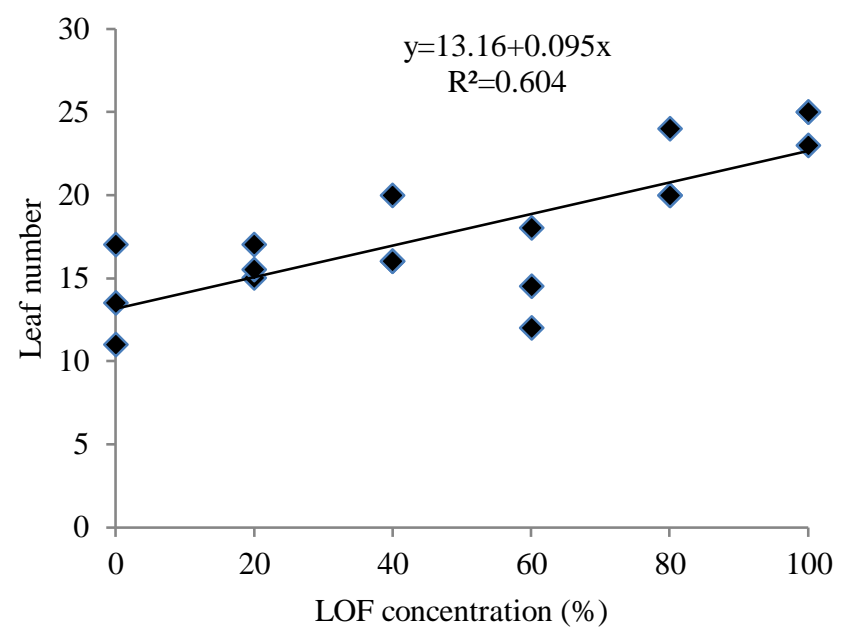

Figure 1: Relationship between the concentrations of water hyacinth-based LOF and leaf number of cucumbers at 6 weeks after planting

Results also revealed that the application of water hyacinth-based LOF increased shoot fresh weight and shoot dry weight of cucumbers. Both increased was linearly responded to application of water hyacinth-based LOF (Figure 2). The relationships were expressed in $y=23.38+0.341 \mathrm{x}$, $\left(\mathrm{R}^{2}=0.637\right)$ and $\mathrm{y}=9.130+0.118 \mathrm{x},\left(\mathrm{R}^{2}=0.651\right)$, respectively. 


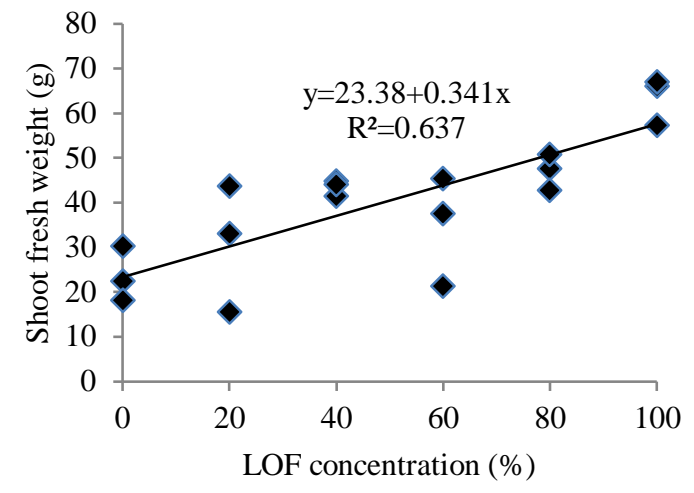

A

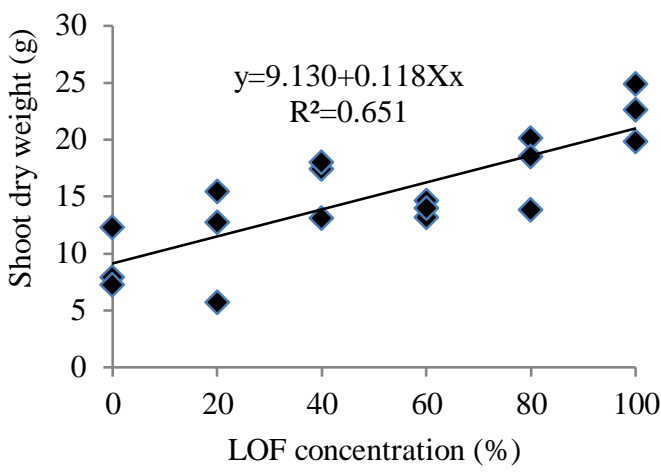

B

Figure 2: Relationship between the concentrations of water hyacinth-based LOF and shoot fresh weight (A) and shoot dry weight (B) of cucumbers

Such linear increased in shoot fresh weight and shoot dry weight of cucumber might have attributed to high $\mathrm{N}$ content in applied LOF (3.08\%) which eventually resulted in rigorous growth of cucumber. According to MARSCHNER (2012) this nutrient plays significant roles in promoting leaf and stem growth of many crops which eventually increases shoot growth. Increasing shoot fresh weight of cucumber was followed by increasing of shoot dry weight (Figure 2B). Cucumbers applied with of $100 \%$ water hyacinth-based LOF had $146.70 \%$ higher shoot dry weight compared to that of control plants. In cucumber, positive effects of $\mathrm{N}$ during the vegetative growth could be expressed by increasing the number of branches and eventually increased the number of leaf formation. Research conducted by MOI et al.(2015) also concluded that the use of water hyacinth-based LOF significantly increased leaf number of caisims (Brassica juncea L.).It appeared that LOF application contributed as much as $63.3 \%$ to the increased of shoot fresh weight, and $65.7 \%$ to the increased of shoot dry weight. The lowest shoot fresh weight was $23.63 \mathrm{~g}$, and the highest shoot fresh weight was $63.43 \mathrm{~g}$. Meanwhile, the lowest shoot dry weight was $9.1 \mathrm{~g}$, and the highest shoot dry weight was $22.45 \mathrm{~g}$. Increased shoot fresh weight of cucumbers could have been resulted from the increasing number of branches and leaves of cucumber due to high $\mathrm{N}$ content in LOF used in this experiment.

\subsection{Cucumber Yields}

Results indicated that the use of water hyacinth-based LOF significantly influenced fruit diameter, fruit length, fruit weight and fruit hardness of cucumbers. Increased fruit diameter was linearly significant with the equation of $\mathrm{y}=3.063+0.009 \mathrm{x}$, and $\mathrm{R}^{2}=0.639$ (Figure $3 \mathrm{~A}$ ), meanwhile increased of fruit length linearly significant with the relationship of $\mathrm{y}=12.66+0.044 \mathrm{x}$, and $\mathrm{R}^{2}=$ 0.468 (Figure 3B). 

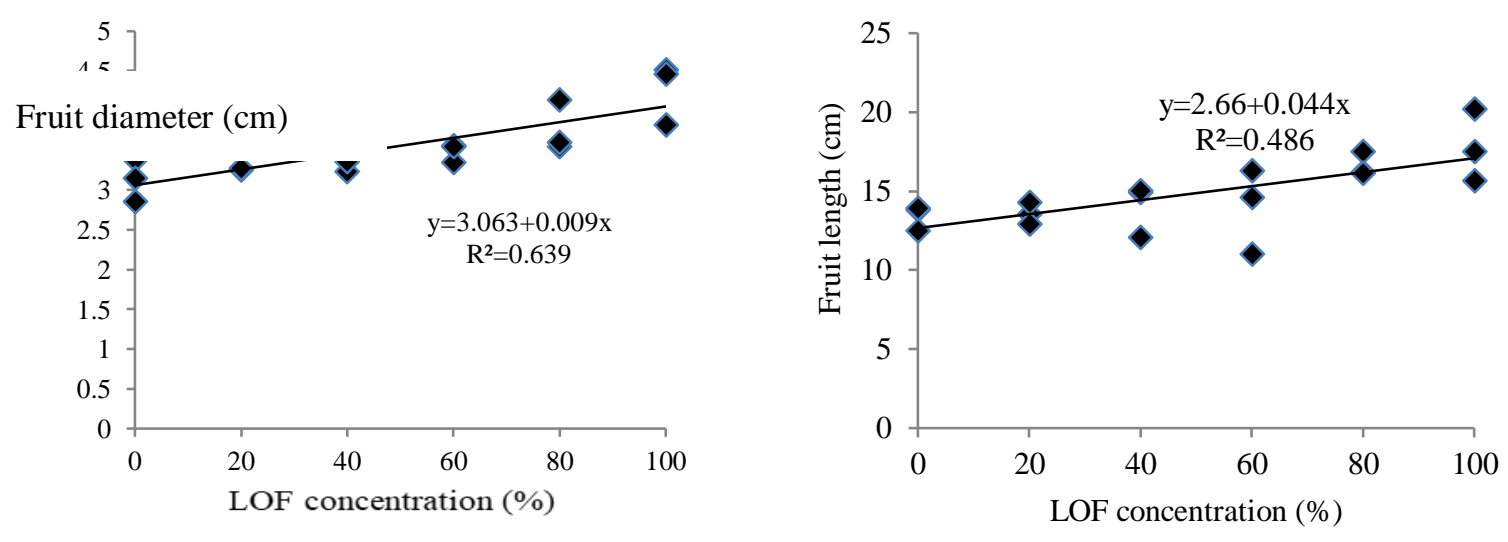

Figure 3: Relationship between the concentrations of water hyacinth-based LOF and fruit diameter (A) and fruit length (B) of cucumbers

Linear increased of fruit diameter due to LOF application was previously reported by using commercial LOF and found that the highest fruit diameter was $4.56 \mathrm{~cm}$ (HASIBUAN, 2014). This diameter was comparable to our results, i.e., $4.26 \mathrm{~cm}$ and it was $36.54 \%$ higher than fruit diameter of cucumber without LOF application. Research conducted by LIDYA et al. (2018) also found that the use of commercial LOF increased diameter of cucumber fruits. Meanwhile increased of fruit length due to application of $100 \%$ water hyacinth-based LOF was $32.75 \%$ higher than fruit length of cucumber without LOF application. The application of $100 \%$ water hyacinth-based LOF produced fruit length of $17.76 \mathrm{~cm}$. This result was in accordance to ANDRIE et al. (2015) who also found that the linear response of cucumber fruit length to commercial LOF.

This experiment also indicated that the use of water hyacinth-based LOF significantly influenced fruit weight and fruit hardness of cucumbers. Fruit weight increased had a quadratic relationship of $\mathrm{y}=106.6-0.954 \mathrm{x}+0.023 \mathrm{x}^{2}$, and $\mathrm{R}^{2}=0.813$ (Figure 4A), while increased of fruit hardness also had a quadratic relationship of $y=2.793-0.003 x+0.0004 x^{2}$, and $R^{2}=0.639$ (Figure 4B). 
International Journal of Agriculture and Environmental Research

ISSN: 2455-6939

Volume: 06, Issue: 06 "November-December 2020"

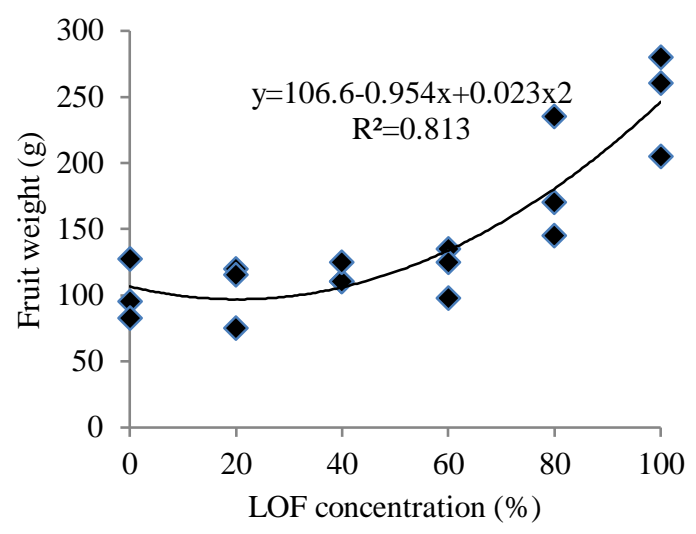

A

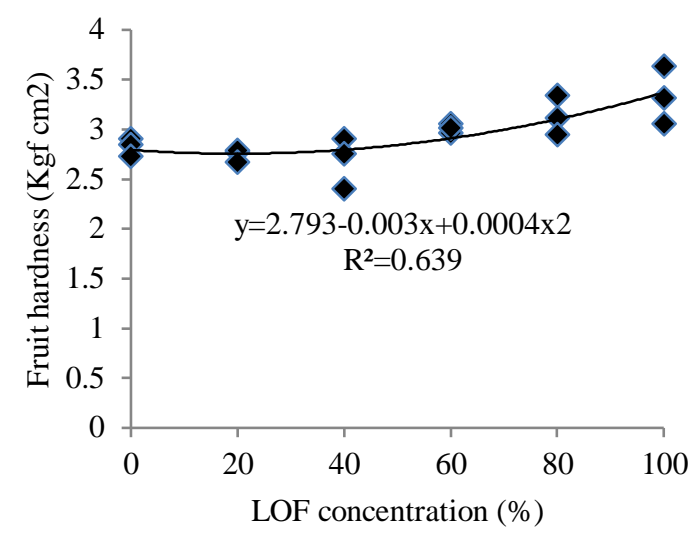

B

\section{Figure 4: Relationship between the concentrations of water hyacinth-based LOF and fruit weight (A) and fruit hardness (B) of cucumbers}

Increased fruit weight (Figure 4A) was likely related to increased fruit diameter (Figure 3A) and fruit length (Figure 3B) of cucumbers. Fruit weight of cucumber applied with $100 \%$ LOF was more than $144 \%$ higher than those of without LOF (248.33 g vs $101.67 \mathrm{~g})$. in addition, the average cucumber fruit weight fertilized with water hyacinth-based LOF was much higher than fruit weight description of Camri F1 (190 g per fruit). This result was in line with that reported by LIDYA et al. (2018) who concluded that of commercial LOF increased fruit weight of cucumber. Higher P content in water hyacinth-based LOF (1.06 \%) might have contributed to this increased. According to SCHACHTMAN et al. (1998), phosphorus plays important roles in optimizing crop growth, yields and quality, including in cucumbers.

The quadratic relationships in Figure 4A and Figure 4B suggested that the magnitude effects of water hyacinth-based LOF to fruit weight and fruit hardness were $81.3 \%$ and $63.9 \%$, respectively. Increased fruit hardness might have due to high $\mathrm{P}$ and $\mathrm{K}$ in LOF. The hardest fruit was found in cucumber fertilized with $100 \%$ water hyacinth-based LOF $\left(3.33 \mathrm{kgf} / \mathrm{cm}^{2}\right)$. Fruit hardness might be resulted from K roles in many enzyme activities (Uchida, 2000) as well as its abundant presence as cations within plant cells (MORGAN AND CONNOLLY, 2013).

This experiment suggested that the coefficient of determination $\left(\mathrm{R}^{2}\right)$ of relationship between the concentration of water hyacinth-based LOF and leaf numberwas 0.604 , while with shoot fresh weight and shoot dry weight were 0.637 and 0.651 , respectively. In addition, the coefficient determinations of relationship between water hyacinth-based LOF with fruit diameter, fruit length, fruit weight and fruit hardness were $0.639,0.468,0.813$ and 0.639 , respectively. These figures implied that the effects of water hyacinth-based LOF highly controlled the performances 
International Journal of Agriculture and Environmental Research

ISSN: 2455-6939

Volume: 06, Issue: 06 "November-December 2020"

of leaf number, shoot fresh weight, shoot dry weight, fruit diameter, fruit length, fruit weight and fruit hardness of cucumbers as much as $60.4 \%, 63.7 \%, 65.1 \%, 63.9 \%, 46.8 \%, 81.3 \%$ and $63.9 \%$, respectively. Such strong effects of water hyacinth-based LOF on cucumber growth and yields provided a positive evidence of the prospect of using this LOF for cucumber production

\section{CONCLUSION}

On the basis of present investigation, it is concluded that the application of water hyacinth-based LOF increased cucumber growth (leaf number, shoot fresh weight and shoot dry weight) and yields (fruit diameter, fruit length, fruit weight and fruit hardness). The best concentration of water hyacinth LOF for increasing cucumber growths and yields was $100 \%$.

\section{ACKNOWLEDGEMENTS}

Thank you to the Faculty of Agriculture, University of Bengkulu for providing area for experiment and use equipment during data collections.

\section{REFERENCES}

ANDRIE, K.L., NAPITUPULU, M.,JANNAH, N. 2015. Respon tanaman mentimun (Cucumis sativus L.) terhadap jenis POC dan konsentrasi yang berbeda. Jurnal Agrifor, 14(1), 1526.

FAHRURROZI., MUKTAMAR, Z., SETYOWATI, N., SUDJATMIKO, S., CHOZIN, M. 2015. Evaluation of tithonia-enriched liquid organic fertilizer for organic carrot production. Journal Agricultural Technology, 11(8), 705-1712. http://www.ijataatsea.com/pdf/v11_n8_15_DecemberSpecialissue/008\%20-\%20Fahrurrozi- $\quad$ S1.pdf

FAHRURROZI, MUKTAMAR. Z., DWATMADJI., SETYOWATI, N., SUDJATMIKO, S., CHOZIN, M. 2016. Growth and yield responses of three sweet corn (Zea mays $L$. var. Saccharata) varieties to local-based liquid organic fertilizer. International Journal Advanced Science. Engineering, Information Technology, 6(3), 319-323. http://dx.doi.org/10.18517/ijaseit.6.3.730

FAHRURROZI, F., SARIASIH, Y., MUKTAMAR, Z., SETYOWATI, N., CHOZIN, M.,SUDJATMIKO, S. 2017. Identification of nutrients content in six potential green biomasses for developing liquid organic fertilizer in closed agricultural production system. International Journal on Advanced Science, Engineering, Information Technology, 7(2), 559-565. http://dx.doi.org/10.18517/ijaseit.7.2.1889 
International Journal of Agriculture and Environmental Research

ISSN: 2455-6939

Volume: 06, Issue: 06 "November-December 2020"

HAJAMA, N. 2014. Studi pemanfaatan eceng gondok sebagai bahan pembuatan pupuk kompos dengan menggunakan aktivator EM4 dan MOL serta prospek pengembangannya. Skripsi.Program Studi Teknik Lingkungan, Universitas Hasanuddin, Makassar.

HASIBUAN, S. 2014. Respon pemberian konsentrasi pupuk herbafarm dan POC keong mas terhadap pertumbuhan dan produksi tanaman mentimun (Cucumis sativus L.) Karya ilmiah Universitas Sumatera Utara, Medan. https://docplayer.info/43784997-Responpemberian-konsentrasi-pupuk-herbafarm-dan-poc-keong-mas-terhadap-pertumbuhandan-produksi-tanaman-mentimun-cucumis-sativus-1.html

LIDYA, E., JANNAH, N., RAHMI, A. 2018. Effect of compost fertilizer and NASA liquid organic fertilizer on the growth and yields of cucumber (Cucumis sativus L.) Misano F1 variety. Jurnal Agrifor, 17(1), 89-96.

MARSCHNER, H. 2012. Marschner's mineral nutrition of higher plants. $3^{\text {rd }}$ ed. Academic Press. London.

MINISTRY OF AGRICULTURE. 2019. Peraturan Menteri Pertanian Republik Indonesia Nomor 01 Tahun 2019 tentang Pendaftaran Pupuk Organik, Pupuk Hayati dan Pembenah Tanah. 47 pages.

MOI, A.R., PANDIANGAN, D., SIAHAAN, P., TANGAPO, A.M. 2015. Pengujian pupuk organik cair dari eceng gondok (Eichhornia crassipes) terhadap pertumbuhan tanaman $\begin{array}{lllll}\text { sawi } \quad \text { (Brassica juncea). Jurnal MIPA, } & 4(1), & 15-19 .\end{array}$ https://ejournal.unsrat.ac.id/index.php/jmuo/article/view/6897/6406

MORGAN, J. B., CONNOLLY, E. L. 2013. Plant-Soil Interactions: Nutrient Uptake. Nature Education Knowledge, 4, 2.

MUKTAMAR, Z., FAHRURROZI., DWATMADJI., SETYOWATI, N., SUDJATMIKO, S., CHOZIN, M. 2016. Selected macronutrient uptake by sweet corn under different rates of liquid organic fertilizer in Closed Agriculture System. International Journal Advanced Science, Engineering, Information Technology, 6(2), 58-261. http://dx.doi.org/10.18517/ijaseit.6.2.749

SCHACHTMAN, D.P., REID, R.J., AYLING, S.M. 1998. Phosphorus uptake by plants: From soil to cell. Plant Physiology, 118, 447-53.

SUHARJO, B., AHMADY, M., AHMADY,M.R. 2016. Indonesian consumers' attitude towards organic products. Advances in Economics and Business, 4(3), 132-140. http://dx.doi.org/10.13189/aeb.2016.040303 
International Journal of Agriculture and Environmental Research

ISSN: 2455-6939

Volume: 06, Issue: 06 "November-December 2020"

SUMPENA, U. 2001. Budidaya Mentimun Intensif dengan Mulsa secara Tumpang Gilir. Edisi 4. Penebar Swadaya.Jakarta.

UCHIDA, R. 2000. Essential nutrient for plant growth: Nutrient functions and deficiency symptoms. In: Plant Nutrition Management in Hawaii's Soils, Approaches for Tropical and Subtropical Agriculture. SILVA, J. A., UCHIDA, R. (Eds). Collegeof Tropical Agriculture and Human Resources. University of Hawaii at Manoa, pp. 31-55. 